\title{
Recent Bushfire Impact on Timber Bridges in Northern New South Wales
}

\author{
Glencross Grant $\mathrm{R}^{*}$ and Moore JC \\ Adjunct Associate Professor in Engineering, Southern Cross University, Australia
}

*Corresponding author: Glencross Grant R, Adjunct Associate Professor in Engineering, Southern Cross University, Australia

Received Date: March 29, 2020

Published Date: April 16, 2020

\section{Abstract}

This paper provides preliminary observations and comments following recent field inspection of a number of fire-damaged bridges in northern New South Wales (NSW). The fire event has been described as unprecedented, at least in living memory, with over five million hectares burnt in NSW from September 2019 to late January 2020, comprising mostly national parks and state forest, but also many neighbouring properties and houses. The impact on infrastructure has been profound, with at least three government schools destroyed and numerous timber road bridges damaged or destroyed in eastern NSW. Some roads have been closed for months and are still closed. These events will have long lasting implications. It is clear that changes will be needed to successfully adapt to altering externalities in the future.

Keywords: Timber bridges; Bushfires; Fire damage

\section{Introduction}

A brief synopsis and comments, based on field inspection by the authors of the impact of the 2019-20 bushfires on timber road bridges in northern NSW, will be provided. The state of NSW has been known as the "timber bridge state" for many years, with over 5000 timber bridges in service at the peak. More recent studies show that there are currently about 1771 timber bridges in service on the road network in the State. Of these about 4\% (66) are on regional roads and about $96 \%$ (1705) on local roads [1]. Regional roads are under the auspices of the NSW state transport department and local roads are under the control of regional local government councils. The study examines three such bridges recently destroyed by bushfires in northern NSW: Hortons Creek and Clouds Creek bridges on the Armidale-Grafton Road and Mann River Bridge (Wytaliba) on Old Grafton-Glen Innes Road. All three bridges were relatively low-level bridges comprising hardwood timber sub-structure (piles, headstocks, corbels and round girders) with concrete decks. The former two had precast concrete deck planks and the latter had a cast-insitu deck.

\section{Inspection and Observations}

The first bridge destroyed in northern NSW this fire season was a low-level timber beam bridge with concrete deck overlay at Wytaliba (29.693S; 152.108E) on the Old Grafton-Glen Innes Road (Figures 1 and 2). It succumbed to a fire in the area on about 8 November 2019. A local resident sadly lost his life at the same time trying to escape the fire storm (Figures $1 \& 2$ ).

After the fires subsided and roads re-opened the authors inspected two other local bridges on 2 January 2020 on the Armidale-Grafton Road at Clouds Creek (30.086S, 152.632E; Figures $3 \& 4$ ) and Hortons Creek (30.000S, 152.680 E; Figures 5 \& 6). The bridge over Clouds Creek sustained damage to two piers including the ends of round timber girders, corbels, ends of piles and headstocks. It was very interesting to see that the fire seems to have ignited the ends of various structural members and progressed along the end grain, and along the central axis, which is not what would normally might be expected for an externally applied fire 
(Figure 4). Because Australian hardwood is very dense ( 1100 $\mathrm{kg} \cdot \mathrm{m}^{-3}$ ) it is unusual for round timbers to ignite on the side of such elements. This observation then prompts a recommendation that more fire-proof protection should be provided to the end grain of structural timber. The bridge over Hortons Creek was difficult to assess because most of the structure had been removed (Figure 6), apart from three girders that were stacked on site. The girders were examined in detail. As would be expected of hardwood, they had charred for about the outer $25-30 \mathrm{~mm}$, however, it was again very noticeable that the fire had also spread along the central axis from the end grain outer face of these members (Figures 3-6).

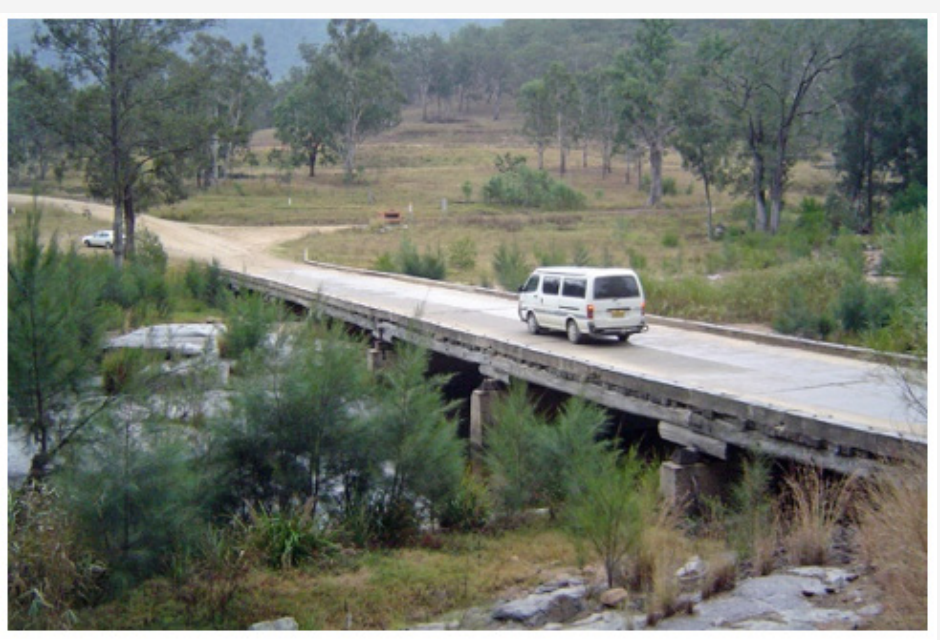

Figure 1: Mann River Bridge, Wytaliba Bridge before fire (Glencross-Gant, 30 April 2007).

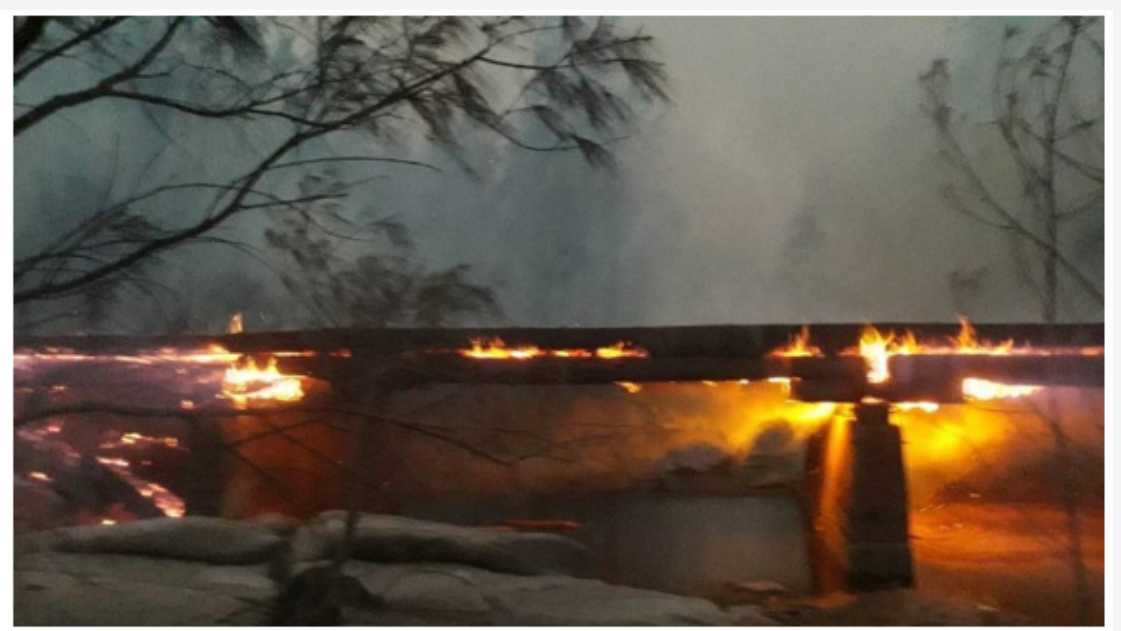

Figure 2: Mann River Bridge, Wytaliba on fire, 8 November 2019 [2].

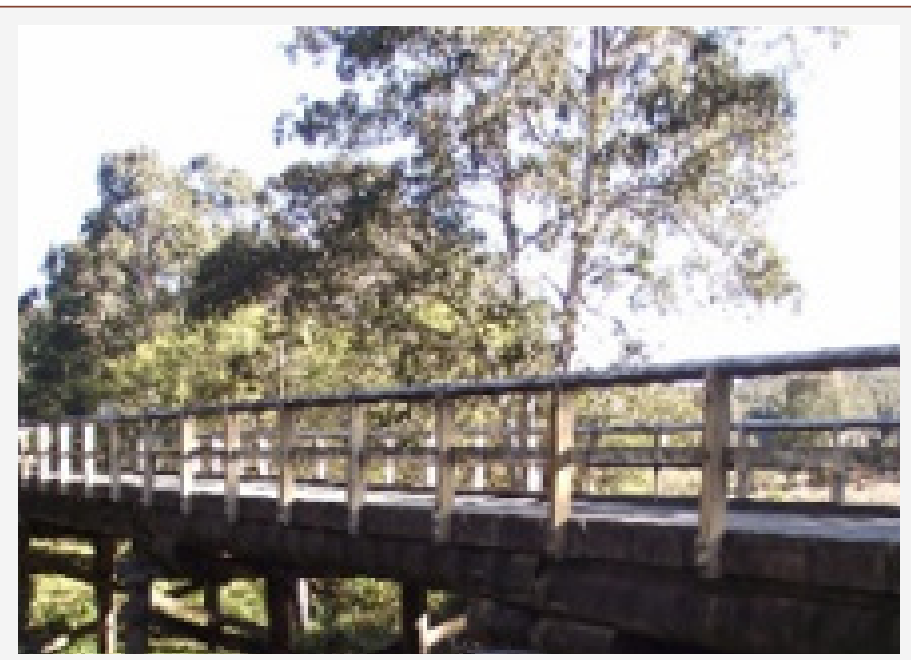

Figure 3: Has this been excessively cropped? before bushfire (Glencross-Grant, 31 August 2015). 


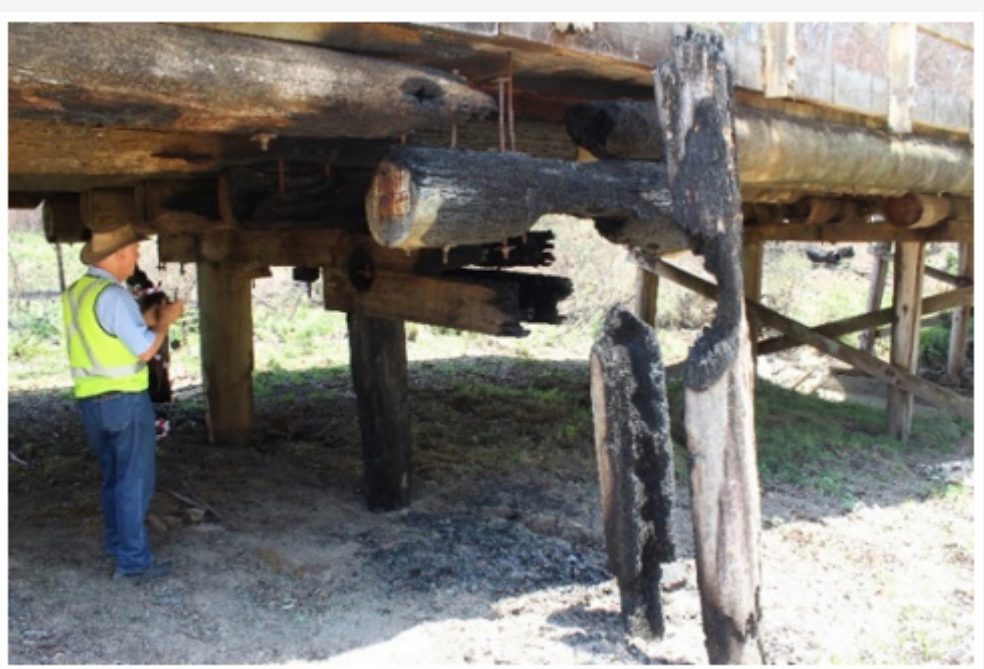

Figure 4: Fire-damaged Clouds Creek Bridge, showing destroyed outer pile, corbel, ends of girders and headstock highlighting end grain progression (Glencross-Grant, 2 January 2020).

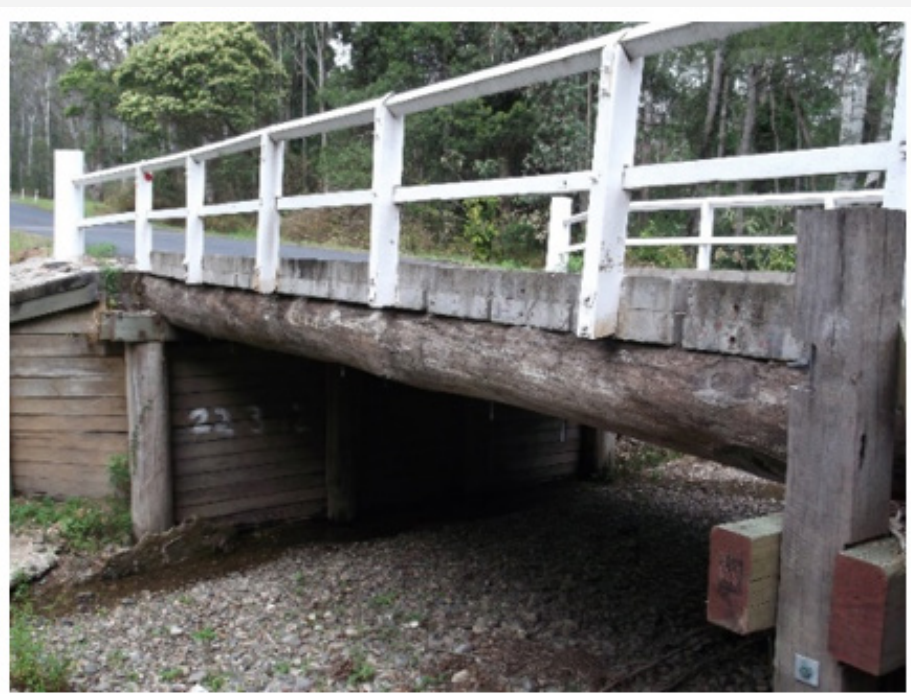

Figure 5: Single span timber Beam Bridge over Hortons Creek (Glencross-Grant, 8 December 2013).

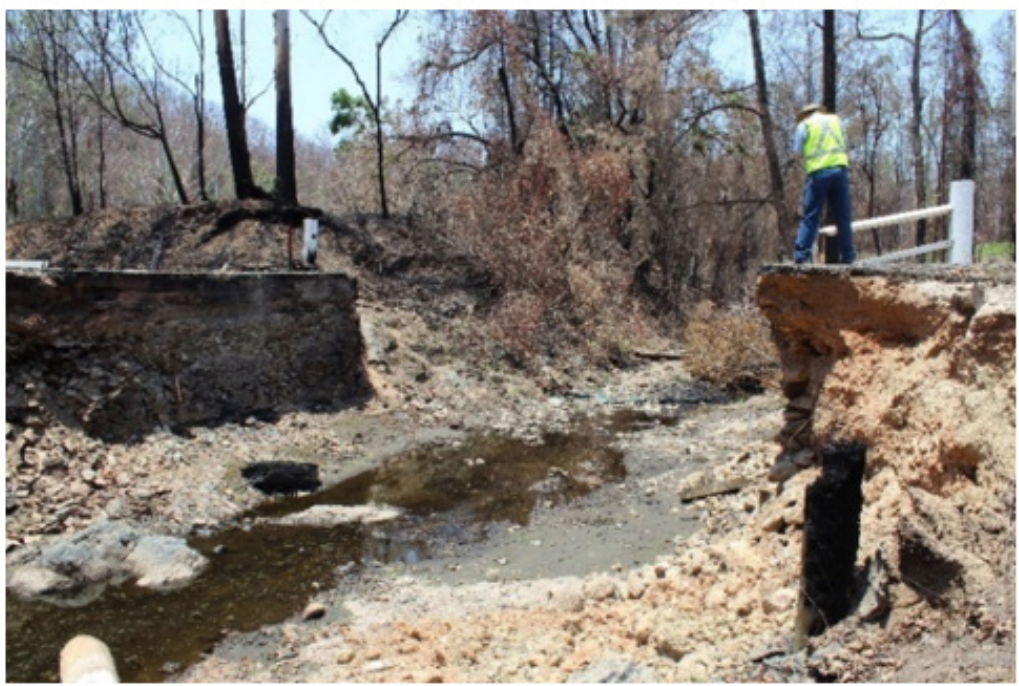

Figure 6: Hortons Creek bridge site, with fire-damaged timber removed (Glencross-Grant, 2 January 2020). 


\section{Comments}

One aspect that was found difficult in preparing this brief paper was the distinct lack of information in the public domain as to the actual structural damage to bridges affected by these fire and flood events. There have been press articles about personal impact, and road closures have appeared on live road apps, but that was about the limit of any detailed information. Even live traffic volume data in the public domain is very, very limited and has been publicly criticised. The authors had had to contact individual colleagues in the various local government areas to gain meaningful data. The damage caused to these bridges resulted from unprecedented bushfires in late 2019 and early 2020 , which occurred at the end of a long dry period. This was immediately followed by a short period of higher than normal rainfall. The intensity of neither had been clearly predicted in time for structures to be appropriately modified. Prior to these failures these structures had provided a reliable level of service for many decades.

\section{Conclusion}

Despite the occurrence of abnormal weather patterns (droughts and longer/hotter summers), it is to be expected that bridges should have a very low probability of failure. To prevent future similar failures re-occurring research is urgently required to upgrade standards to include the types of failure modes reported here. In particular simple changes could be made to the protection of exposed end-grain timber by improved detailing. Additionally, maintenance inspection and work regimes could be reviewed in terms of frequency, to ensure a greater level of preparedness.

\section{Acknowledgement}

None.

\section{Conflict of Interest}

No conflict of interest.

\section{References}

1. Verit S (2017) Timber Bridge Management Report, in Road Asset Benchmarking Project, IPWEA (NSW) Roads and Transport Directorate. Institute of Public Works Engineering Australasia (IPWEA): Sydney.

2. Glen Innes Examiner (2019) Kangawalla fire: tragedy as firefighters battling Kangawalla fire near Glen Innes discover body in car. 